\title{
NBSIR 77-1382
}

\section{Visiting Team Report on 1977 Industrial Survey in Korea on Precision Measurements and Standards}

KunMo Chung

H. Steffen Peiser

Raymond C. Sangster

Office of International Relations

National Bureau of Standards

Washington, D.C. 20234

Korea Industrial Survey carried out during calendar year 1977

Prepared under a Memorandum of Understanding between the National Bureau of Standards and the Industrial Advancement Administration, Ministry of Commerce and Industry, Seoul, Korea

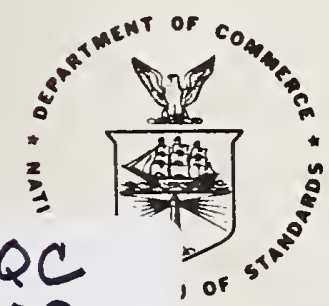

100

. U56 JARTMENT OF COMMERCE

$\forall 77-1382$. BUREAU OF STANDARDS

1977 
NBSIR 77-1382

VISITING TEAM REPORT ON 1977

INDUSTRIAL SURVEY IN KOREA ON

PRECISION MEASUREMENTS AND

STANDARDS

KunMo Chung

H. Steffen Peiser

Raymond C. Sangster

Office of International Relations

National Bureau of Standards

Washington, D.C. 20234

Korea Industrial Survey carried out during calendar year 1977

Prepared under a Memorandum of Understanding between the National Bureau of Standards and the Industrial Advancement Administration,

Ministry of Eommerce and Industry, Seoul, Korea

U.S. DEPARTMENT OF COMMERCE, Juanita M. Kreps, Secretary

Dr. Sidney Harman, Under Secretary

Jordan J. Baruch. Assistant Secretary for Science and Technology

NATIONAL BUREAU OF STANDARDS, Ernest Ambler, Acting Director 
TABLE OF CONTENTS

Page

I. INTRODUCTION . . . . . . . . . . . . . . . . . . . 1

II. K-SRI SURVEY PLAN . . . . . . . . . . . . . . . . . 3

III. WORKSHOP PROCEEDINGS . . . . . . . . . . . . . . . 9

IV. VISITING TEAM RECOMMENDATIONS . . . . . . . . . . . . . 11

V. CONCLUDING REMARKS . . . . . . . . . . . . . . . . 15

APPENDIX A: VISITING TEAM ITINERARIES . . . . . . . . . . . 17

APPENDIX B: IMPORTANCE AND USEFULNESS OF THE NATIONAL

MEASUREMENT SYSTEM STUDY (a lecture) -

R. C. Sangster . . . . . . . . . . . . 19

APPENDIX C: A SAMPLE QUESTIONNAIRE SUGGESTED BY THE VISITING

TEAM • . . . . . . . . . . . . . . . . 21

APPENDIX D: DRAFT OF A LETTER TO ACCOMPANY THE QUESTIONNAIRE • • . 23 


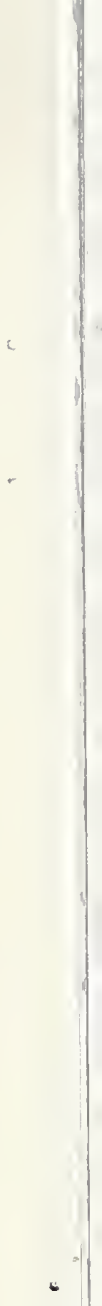




\section{INTRODUCTION}

The creation of the Korea Standards Research Institute (K-SRI) In December 1975 was based on the needs of Korean industrial development as seen by the Government of the Republic of Korea. A feasibility study executed by the General Electric Company Tempo Division provided a basic plan for the national standards system of Korea. In late 1974, drafts of the Tempo Report were discussed with Dr. Zae-Quan KIm, who is now President of K-SRI, and with members of the National Bureau of Standards. Through a USAID (U.S. Agency for International

Development) Loan and a formal Memorandum of Understanding with the Industrial Advancement Administration of Korea, NBS now actively supports the Institution building process of $\mathrm{K}-\mathrm{SRI}$.

It became clear by early in 1975 that K-SRI needed a more precise understanding of the metrological needs of industry than was provided in the Tempo Report. Dr. Kim, in discussion with Mr. Peiser, proposed a sequence for the development of activities as follows:

1. Industrial survey,

2. hiring of K-SRI staff,

3. major decisions on instrumental systems for $K-S R I$, and

4. architectural plans for laboratory bulldings.

As time went on, the restraints of urgency enhanced by unexpected delays and the initial lack of an even remotely adequate local currency (Won) budget forced a sequence to be followed which was roughly in reverse of the above order.

It is obvious that the original purpose of the Industrial survey for planning K-SRI staff capabilities and laboratory facilitles had largely disappeared by mId-1976. When in $\mathrm{K}-\mathrm{SRI} / \mathrm{NBS}$ correspondence the Idea was revived in January 1977 with emphasis on the instrument manufacturing industry in Korea, NBS was not favorably inclined on mounting such a survey with significant effort, and Dr. KIm himself informed NBS that the initiative did not have his support, but that a revised plan would be furnished shortly. NBS confirmed that continuing assessment of Korean Industrial needs was an essential requirement for $\mathrm{K}-\mathrm{SRI}$, and an industrial survey of some kind might be frultful at any time.

In April 1977, NBS was confronted with an urgent request to mount a team visit at high level to help to guide a very major K-SRI industrlal survey in Korea. There were no detalls except that a sequence of major events was foreshadowed. When NBS showed reluctance to be involved in such a survey in view of the lack of adequate information, K-SRI representatives insisted that NBS help was needed. 
When in mid-May 1977 Dr. KIn visited NBS, he brought the first technical deta1ls of the survey plans. They were mostly embodied in a major questionnalre to be completed by about 3,700 Korean companies. Together w1th other NBS/K-SRI programs, a revlew was organized on May 17 in the presence of Professor KunMo Chung of the Polytechnic Inst1tute of New York.

With Dr. Kim's explanations and enthusiasm, an understanding was reached at the meeting for the survey to be mounted. Suggestions made at that meeting in connection with questionnaires, survey scales, and analytical approaches were well received by $\mathrm{Dr}$. Kim and K-SRI members.

K-SRI, after all, did need the most thorough and complete understanding of Industrial metrological needs of Korea now and throughout its existence. How else could such a modern facility justify itself and its budgetary support? NBS thus decided to make a three-man team available for a workshop in Seoul on May 23 - 24 to discuss the technical aims and methodologies of the survey. They were to make suggestions in consultation with a widely representative group on the questionnaire, on the follow-up visits of K-SRI staff to selected companies, and on the subsequent analysis of the data. This report sumarizes the technical and consultation activities by the visiting team in Seoul. 


\section{K-SRI SURVEY PLAN}

Detailed planning of the "Industrial Measurement Survey in Korea" was carried out by the K-SRI staff members in Seoul, Korea. Based on the official letters from the K-SRI management to the NBS office of International Relations in early 1977 and preliminary documents prepared in Korea, the K-SRI proposed survey can be summarized as follows :

\section{(A) OBJECTIVE}

The primary objectives of the survey were originally set as:

1. a comprehensive reassessment of the current status of the national measurement system in Korea to formulate the program for strengthening the infrastructure of the natiomide calibration network;

2. delineation of the qualitative extent of services to be offered through the specification of the diverse kinds of services and the varied types of equipment susceptible to $\mathrm{K}$-SRI services; and

3. collection of technical and economic data on client firms to enable a correlation of this data with the work load for calibration and the SRM/MAP* program at $\mathrm{K}-\mathrm{SRI}$.

In addition, the following secondary objectives were given:

4. identification of problems in measurement practices to formulate an effective technical assistance program for small and medlum industries; and

5. collection of basic data for a nationwide laboratory accreditation program to be undertaken in the near future.

According to a communication subsequent to our visit, however, $\mathrm{K}-\mathrm{SRI}$ simplified the purpose of the survey and confined the initial objective to finding the currently available levels of precision of 26 measurement categories (similar to those of the NBS Study of the U.S. National Measurement System) in the Korean industry and assessing the need of calibration service for Korean high-technology firms.

‡Standard Reference Material/Measurement Assurance Program $m$ 
(B) SURVEY SCHEDULE

A number of activities were planned for the proposed survey. According to the "Schedule for 1977 National Census on Precision Measurements and Standards" (in Korean and dated March 1977), the survey would be conducted as follows:

(1) Preparatory Phase (from February 1 to June 30)

- Preliminary work - Information collection on the scope of survey review of related statistical data.

- Preparation of survey questionnaire.

- Preparation of slides and brochures to inform the public and Industry of the importance of the survey.

- Preparation and posting of official announcements.

- Consultation with the Industrial Advancement Administration, the Economic Planning Board (EPB), and the Ministry of Commerce and Industry.

- Consultation with the U.S. National Bureau of Standards.

- Pilot survey with draft questionnaire and final adjustment of the survey documents.

- Survey workshops and seminars in major cities.

- Offictal approval from EPB for compiling statistics (to meet the legal requirements).

(2) Main Phase (from June 1 to December 20)

- Announcement of survey teams and schedule.

- On-the-job training of survey team members.

- Distribution of questionnaires and field surveys.

- Review of returned questionnaires.

- Preparation of Electronic Data Processing System for the survey.

o Compilation of the statistics and data. 
- Review of workshops and seminar performances.

- Preparation of reports.

- Officlal approval of the survey report by EPB.

- Publication of the survey report.

(It should be noted that the above schedule was out of date, since the survey objective was significantly simplified. The final schedule was not set as of May 31, 1977.)

(C) SURVEY SCOPE

According to the K-SRI plan, the survey would be conducted in 26 measurement categorles and would cover 295 measuring equipments and standards. The selected categorles were:

length and angle, mass, volume, and density, force, vibration and shock, pressure and vacuum, fluid flow, thermodynamic properties of fluids, electricity, electromagnetics, time and frequency, acoustics, ultrasonics, temperature, cryogenics, humid1ty, lonizing radiation, physical properties of atoms and molecules, far ultraviolet radiometry, spectrophotometry, radiometry and photometry, optics, laser, surface fintsh, surface property, materials testing, and chemical analysis.

Based on preliminary examination, more than 3,700 institutions were selected as targets for the survey. The K-SRI plan 11sts them as follows : 


\section{Public Institutions}

national standards institution $\quad 1$

academic institutulons 200

testing and Inspection agencles 20

defense agencies $\quad 50$

central administrative agencies $\quad 20$

local administrative units 10

standardization agencies 1

observatories 2

broadcasting stations 5

health and medical Institutions 50

economic and industrial organizations 14

Private Firms

agricultural, fishing, and mining 10

clvil and construction 10

transportation 50

food, textile, clothing, paper, and printing 350

non-metal materials 115

chemical, plastics, rubber, and petro-

chemical

320

Iron, steel, and foundry 150

metal and machine $\quad 1027$

electronics and communication 823

transportation equipment $\quad 144$

metrological equipment 240

$\begin{array}{ll}\text { other services } & 100\end{array}$

Among these survey targets, more than 800 institutions were selected

for on-site visits.

(D) QUESTIONNAIRE

K-SRI prepared an extensive questionnaire for the survey. According to the questionnaire, a number of organizations were to be involved in the survey as follows:

Supervising Organization

Industrial Advancement Administration

Cooperating Organizations

Economic Planning Board

Ministry of National Defense

Ministry of Science and Technology 
Consulting Organizations

U.S. National Bureau of Standards

USAID - Korea

Executing Organization

Korea Standards Research Institute

Supporting Organizations

Korea Standards Association

Korea Institute of Sclence and Technology

Korea Atomic Energy Research Institute

Korea Advanced Institute of Sclence

Natlonal Industrial Research Institute (NIRI)

Fine Instrument Center (FIC)

Korea Electrical Apparatus Testing and Inspection

Foundation

Korean Gage Meters Association

Korea Society for Advancement of Machine Industry

Korea Chamber of Commerce and Industry

Korea Trade Association

Korea Gage Meter Industry Cooperation

Federation of Korean Industries

Korea Federation of Small Businesses

The questionnaire consisted of elght parts:

Part 1 - Organizational overview

Part 2 - Manpower and technical capability in precision measurement

Part 3 - Training programs in measurement

Part 4 - International cooperation and technology

Part 5 - R\&D activities in measurement

Part 6 - Production of measuring equipment

Part 7 - Salary scale for manpower in measurement

Part 8 - Use rates and levels of precision measuring equipment

In total, the questionnaire was 32 pages long and contained over 6,000 blanks to be answered.

(E) SURVEY REPORT

No specific information was available for the final survey report. However, during one consultation session, it was pointed out that K-SRI would produce a report of various statistics and numbers 
generated by complling data from the questionnalres. There are many similar statistical books prepared by government agencies in Korea. K-SRI was considering publication of such extensive statistical books on the Korean standards system as of 1977. Apparently many Korean

Government officials consider highly such statistical compilation and encouraged K-SRI to undertake an industrial survey to produce a comprehensive statistical book on measurement equipment and measurement activities. 
The preparatory workshop for the "1977 Industrial Precision Measurement Standards Survey" was held as a scheduled event of the survey. It was planned by the K-SRI survey officlals in order to promote the understanding of the proposed survey among supporting organizations and survey target institutions. In addition, K-SRI officlals intended to use the workshop for launching the main survey activities.

The workshop was held in the $\mathrm{K}$-SRI conference room at 2:00 p.m. on Monday, May 23, 1977. In Dr. Zae-Quan Kim's absence abroad, Dr. Wun Jung, Vice President for Metrology, presided. More than 100 people from participating organizations and industrial firms attended the workshop. The workshop program was as follows:

1. Opening Remarks - Dr. Wun Jung

2. Status Report on the Survey - Mr. S. S. KIm

3. NBS Movie on "Standards for Excellence" - commentary by Mr. H. S. Pelser

4. Lecture on "Importance and Usefulness of the National Measurement System Study" - Dr. R. C. Sangster

5. Comments on "Measurement Activities and Industrialization" - Dr. K.M. Chung

6. Closing Remarks - Dr. J.W. Choi

In the opening remarks, Dr. Wun Jung welcomed the participants and the NBS visiting team. Dr. Jung expressed his appreclation of the support given to $\mathrm{K}-\mathrm{SRI}$ by NBS and other participating organizations.

Mr. S. S. Kim, the principal K-SRI staff member in charge of the survey, briefly described the background of the survey and the main features of the survey activities. He also explained the survey scope and schedule.

The ABS movie on "Standards for Excellence" ran for approximately 30 minutes. It showed the Importance of standardization in daily life and modern socleties. The example of fire fighting impressively demonstrated the need for standardization. After the movie, Mr. Peiser expressed the team's appreciation of the local hospitality and congratulated the $\mathrm{K}-\mathrm{SRI}$ leadership in making rapid progress in institution building and recrultment of competent staff members. He also commented on the importance of the survey for future K-SRI contributions toward Korean industrial development.

Dr. Sangster then gave the lecture on "Importance and Usefulness of the National Measurement System Study," which he had headed in the 
U.S.A. In h1s lecture, Dr. Sangster explained the systems approach in examining the national measurement system. He reminded his audience that the measurement system is dynamic in nature. Based on his own experfence in conducting the NBS study of the National Measurement System, he gave several tips for carrying out the survey. One example was that procurement people can be a very important information source on the precision levels of materials required in the industry. (The full text of Dr. Sangster's lecture is given in Apprend1x B.)

Following Dr. Sangster's lecture, Professor Chung gave a short speech on "Standardization and Industrialization." He pointed out that technological progress in developing countries follows "reverse" development flow. Normally technologlcal progress starts from R\&D activities to marketing. However, in developing countries, the market develops ahead of the scientific and technological capabilities. In Korea, which is going to be an export-orlented Industrialized nation, the Industry is moving into high technology flelds. Levels of needed high precision are increasing and quality control requirements are getting tougher. This 18 why K-SRI was established to assist the Korean industry in upgrading measurement capabilities and accelerating standardization.

The closing remarks for the workshop were delivered by Dr. J. W. Choi, Administrator of the Industrial Advancement Administration. Dr. Choi mentioned that industrlalization can be judged from two aspects: material-wise or manpower-wise. Unt1l now Korea has trled to increase output and has only been concerned with material-wise industrialization. However, the time has come to pay attention to people's capability in industrlalization. For example, 94 percent of Japanese firms employ quality control programs, whereas in Korea, only 4 percent of the industrial firms have them. Thus, the Korean industry has neglected an important element of industrialization. The Korean Government established K-SRI with the hope of upgrading the capability of measurement, by which quality can be introduced into the industrialization. The success of K-SRI depends on the cooperation it may receive from the 1ndustry. Dr. Chol urged the Korean Industry to give full support for the survey, which is the first K-SRI project. 


\section{VISITING TEAM RECOMMENDATIONS}

After reviewing the K-SRI planning documents and completing participation in the workshop, the visiting team made a series of recommendations in connection with the survey. These recomendations were explained to the K-SRI management and survey officials in consultation meetings. Also the visiting team made an offical visit to Dr. J. W. Chol, Administrator of the Industrial Advancement Administration, and explained the team's views of the survey.

Conclusion 1: The team concluded that an industrial survey is indeed very much needed. The GE Tempo Report is not sufficient, and a fullscale survey will benefit not only K-SRI but also other agencies Involved in Korean Industrialization.

Recommendation 1: K-SRI should continue survey activities at all times in order to ascertain the current status of the measurement activities and formulate relevant programs at $\mathrm{K}-\mathrm{SRI}$.

Conclusion 2: Whereas the original objective of the survey was well expressed, the team considered that it was too broad and could not be realized in a six-month project. However, the simplified objectives could be within the reach of the present K-SRI capability, provided that substantial external assistance and close cooperation from related Korean agencies and industry could be mobilized in time.

Recommendation 2: $\mathrm{K}$-SRI should start the inftlal survey in finding the critical measurement problems in strategic industrial sectors which are designated by the Korean Government as the nucleus of the Korean industry.

Conclusion 3: The survey should benefit K-SRI in the first place. The result of the survey should be able to provide inputs to K-SRI for planning of its specific research programs.

Recommendation 3: The survey activities should be used to educate K-SRI staff members about industrial activities and to provide opportunities for establishing cordial working relations between K-SRI and Korean Industry.

Conclusion 4: K-SRI staff is numerically too small to conduct an effective statistical analysis of thousands of questions asked of thousands of firms.

Recommendation 4: A lower priority should be given to the compilation of statistical data. If the Korean situation dictates and K-SRI resources can afford the effort, the census type of survey may be 
carried out as a part of the entire exercise. However, statistical compliation and listing of equipment would be unlikely to render important conclusions on the present measurement activities or insights on the measurement problems in Korean industry.

Conclusion 5: The questionnaire is overly ambitious and is not likely to succeed in meeting the purposes of the survey. Even if the questionnaires were well returned, K-SRI would become submerged in a sea of data. There are, moreover, questions in the draft questionnaire which may offend the respondents and create suspicions among industrialists.

Recommendation 5: The draft questionnaire prepared by K-SRI should be simplified. The visiting team prepared a draft questionnaire which might be used as the basis for development of a modified questionnaire for the survey. This draft sample questionnaire is given in Appendix C. (This recommendation was adopted by the K-SRI survey officials, who prepared a survey questionnaire based on the sample questionnaire given here.)

Conclusion 6: The success of the survey depended on careful attention being given to the problem of filling out questionnaires, of tabulating the results, and of using the results. Considering that two methods of approaching respondents, by mail and by on-site visits, will be used for the survey, the questionnaire(s) must be prepared for functional use in both cases.

Recommendation 6: To assist comprehension of the purpose of the survey by respondents reached by mall, an additional explanatory letter should accompany the questionnaire. The team drafted such a letter as given in Appendix D.

Conclusion 7: Industrial firms may be inclined to give only a minimum of thought and attention to the questionnaire, and that may not be adequate for the full aims of the survey.

Recommendation 7: In conducting the survey, K-SRI officials should be patient and persuasive. They should not expect that the respondents would fill out the questionnaire immediately. After mailing the questionnaire, K-SRI could follow up with polite letters requesting the responses, and, later on, contact them by telephone calls. After recelving the filled-out questionnaires, K-SRI should send thank-you notes for cooperation. K-SRI officials must remember that K-SRI exists to serve rather than to regulate the industry.

Conclusion 8: Some detailed work is needed to anticipate likely reactions of respondents and problems in analysis by K-SRI. 
Recommendation 8: Before distributing the questionnaire, it should be tested internally. Then, the questionnaire should be reviewed with other interested parties such as FIC and NIRI people. Afterwards, the questionnaire must be tested by on-site visits to "test companies" which are located conveniently and are potentially interested in the survey. Based on their responses and comments, the final questionnaire should be developed.

Conclusion 9: The purpose of on-site visits is threefold; one is to get answers to the questionnaire, another is to develop fruitful continuing relationships between K-SRI and the industry, and the third is to educate $\mathrm{K}$-SRI staff members about industry.

Recommendation 9: Every visiting team should always include both a permanent K-SRI staff member and a person experienced in the industrial sector. On-site visits should be carried out at selected industrial firms and organizations which are identified as important for the survey. The number of on-site visits should not be too large. Four or five firms in one industrlal sector will be sufficient in providing the pertinent information for that sector.

Some companies should be industrial leaders; some should be chosen at random from small and medium-sized organizations. All parts of the country should be visited.

Conclusion 10: The success of on-site visits will be based on careful approaches and correct attitudes during interviews.

Recommendation 10: Some useful tips for the interviews are as follows:

o Always clear the visit through the top official in the company or plant.

o Interview the heads of the following departments or activities:



- Meet the working people who are making measurements and observe their measuring activities. 
- Try to relax the respondents - some wlll start belng fearful or annoyed.

- Use the questionnalre form in recording the answers.

- Probe to uncover the problems that have not yet been recognized as measurement-related.

Conclusion 11: Having read the NBS reports on the measurement categorles in the U.S. Natlonal Measurement System Study, K-SRI staff members 111 be in stronger positions to 1dentify measurement problems and may be able to provide some immedlate technical assistance to respondents. This would amplify the usefulness of the survey.

Recommendation 11: K-SRI could draft the outline of the final report(s) early in the survey. A good starting reference point would be the NBS reports on the study of the U.S. national measurement system.

Final reports can consist of two parts; one would cover qualitative measurement problems in key industrlal sectors such as the metallurgical industry, machine industry, electronics industry, transportation industry, chemical industry, and metrology industry; and the other would contain the overall compllation of survey results. If necessary, K-SRI might also produce technical reports of some selected measurement categories.

Conclusion 12: Some K-SRI staff members requested and probably needed help in their presentations to members of industry and the technical publ1c.

Recommendation 12: The preparation of several well-written speeches and case storles would help. These can be used to demonstrate the importance of high-precision measurements and standardization.

Using some collected "reject" products, K-SRI could also prepare some "show and tell" demonstrations. These speeches, case storles, and demonstrations should be used throughout the survey. They might be effective for promoting $\mathrm{K}$-SRI causes. 


\section{CONCLUDING REMARKS}

The visiting team went to Korea with certain reservations and worries about the survey. Although the quarterly review meeting held at Washington in May 1977 cleared many doubts, the team was not sure whether K-SRI survey officials would accept its recommendations wholeheartedly. Also, there were many organizations involved in the survey, and the team was not sure how they would react to the recommendations. Because Dr. Z. Q. K1m, the K-SRI President, was on a recruiting tour in the U.S., he was unable to attend the workshop and instruct the $\mathrm{K}$-SRI staff members of the changes made during the Washington meeting. In fact, the visiting team conveyed without difficulty his modified views about the survey to the K-SRI staff members.

After completing the workshop and consulting sessions, the visiting team was very enthusiastic about the positive response it had received. The workshop was well attended by representatives from related (and possibly competing) organizations and Industry. IAA was in full support of the survey, and, to the satisfaction of the visiting team, Dr. Chol was very much in agreement with the recommendations. Clearly, K-SRI staff members are competent and highly trained, hard-working specialists. The visiting team saw a great potential in $\mathrm{K}-\mathrm{SRI}$ and the survey.

Most of the recommendations made by the visiting team were adopted by the K-SRI survey officials. A new questionnaire was drafted, and the survey scope was rearranged. Intensive work related to the report preparation was initiated. The K-SRI technical staff members responded to the suggestions with enthusiasm and eagerness. The team had a clear impression that their visit was useful in removing doubts and confusion in connection with the survey planning and implementation.

In spite of the newly-won optimism about the survey, the visiting team would like to note that there still exist many dangerous traps for the survey. K-SRI survey officials must digest well the primary objective of the survey and should remember that some of the recommendations are easy to say but very difficult to implement. For example, establishing a good relationship with industry may not be easy. Patlence, humility, understanding, integrity, and hard work must characterize all K-SRI workers.

It must be stressed that "crisis management" has a limit for success and must be avoided. As a young institution, K-SRI will have its fair share of "crisis management," but the team hopes that there will not 
be any need for "crisis management" In completing the present subject survey.

Finally, the visiting team wishes to express its sincere appreciation of the cooperation and hospltality shown to them by the K-SRI management and staff members during their visit to Seoul. The team is also greatly Indebted to Dr. J. W. Chol of the Industrial Advancement Administration and USAID officials for their advice and assistance. 
APPENDIX A

\section{VISITING TEAM ITINERARIES}

Saturday, May 21 Arrival of Mr. H. Steffen Peiser

Sunday, May 22

Visit to DaeDuk K-SRI Construction Site by Mr. H. Steffen Pelser

Arrival of Dr. Raymond C. Sangster

Reception by Dr. Jong Wan Choi, Administrator of the Industrial Advancement Administration

Arrival of Dr. KunMo Chung

Monday, May 23

Offical Team Visit to K-SRI Headquarters

Workshop at K-SRI Conference Room

Reception by Dr. Wun Jung, K-SRI Vice President

Tuesday, May 24 Official Team Visit to IAA

Official Team Visit to USAID

Consultation Meeting with K-SRI Survey officials

Wednesday, May 25 Team Review Meeting at Hotel

(National Holiday)

Consultation Meeting with K-SRI Staff Members

Departure of Dr. Raymond C. Sangster

Thursday, May 26

Administrative Consultation Meeting with K-SRI Management

Departure of $\mathrm{Mr}$. H. Steffen Pelser

Revlew of Survey Questionnaire

Friday, May 27

Consultation Meeting with K-SRI Survey officials on Field Visits

Consultation Meeting with K-SRI Survey officials on Final Reports 
Saturday, May 28

Tuesday, June 12

Wednesday, June 13
Final Review of the Survey Plan

Review of the Team Vis1t with Dr. Zae-Quan Kim

(President) and Dr. Wun Jung (VP)

Departure of Dr. KunMo Chung 
APPENDIX B

IMPORTANCE AND USEFULNESS OF THE

NATIONAL MEASUREMENT SYSTEM STUDY

(a lecture)

R. C. Sangster

Secondary industry in Korea has grown rapidly since 1960. It is now time to establish an advanced industrial structure and higher product quality control. This industrial changeover urgently requires strengthening the Korean national system for making physical measurements. As you are well aware, the Korea Standards Research Institute was created to meet this need.

A complete understanding of the present status and the changing trend of industrial measurement is now vitally important. I understand that this work began in 1973, when the National Industrial Standards Research Institute initiated the "industrial measurement survey for establishment of a measurement standards system." Any national measurement system is dynamic and changes rapidly. Shifts come from growth of the industrial economy and technical innovation.

Since 1966, the National Bureau of Standards (NBS) in the United States has developed a systems approach to understanding our national measurement system. This approach provides information for long-range policy decisions. It supports adjustment of the NBS program to meet changing national needs for measurements. In our comprehensive study of the national measurement system during the years 1972-75, we placed major emphasis on clarification of the economic impact of measurementrelated activities. The final report of this study consists of 27 individual reports. Topics range from "Final Summary Report" through "Transactions in the National Measurement System" to discussions of 22 technical measurement sectors.

The economic analyses showed that measurement-related activities account for about six percent of the U.S. gross national product. Today, this is about $\$ 100$ blllion. Labor costs about 85 percent of this total. The rest is the cost of equipment and facilities. There are over 300 standards and calibration laboratories in the United States. They are found in industry, goverment, universities, and independent research organizations. Many are members of the National Conference of Standards Laboratories. This organization has quite a number of non-U.S. members also, including several in this part of the world. The parent companies of U.S. members produce about $\$ 200$ billion, or 15 percent of the gross national product, on a value-added 
basis. Of this amount, at least $\$ 20$ billion is directly related to the measurement activities of these laboratories. These laboratory activities cost around $\$ 230 \mathrm{~m} 111$ ion.

In each technical measurement sector, the study revealed urgent problem areas. NBS has adjusted its programs to direct its efforts in these areas. Parenthetically, my biggest problem has been to get the authors of these detalled studies to complete writing their reports. Many tell me they are so busy working on these new problems that they can't find time to write. In other words, the studies were so successful that I am having a hard time in succeeding in getting the reports issued.

A very important part of the total measurement system is the instrumentation industry. As science and industry grow and industrial technology advances, measurement instrumentation technology must also advance. Both strengthening the institutions in the measurement system and development of the instrument industry are needed to support industrial development. In the case of Japan, the total sales of precision measurement instruments in 1975 were about \$1.6 billion. of this, $\$ 330$ million was exported and $\$ 260$ million imported. In the United States, total measurement instrumentation production is around $\$ 2$ billion, of which about half is exported. It seems evident that the development of the instrument industry in Japan has played a key role in Japanese industrial advancement since 1950.

A complete analysis of Korean industrial measurements will be very useful. It will show both current status and the changing trends. It w1ll help define the immediate responstbilities of the national standards organization. It will help that organization to meet changing national needs and to formulate policies to promote the development of instrument industries. 
COMPANY NAME:

Address :

Principal Products:

Approximate No. of Employees:

Approximate No. of Measurement Technictans or Metrologlsta:

NAME OF RESPONDENT:

Title or function:

Address 6 Telephone No:


Continue answers on the back or other paper when opace 1 s not adequate.

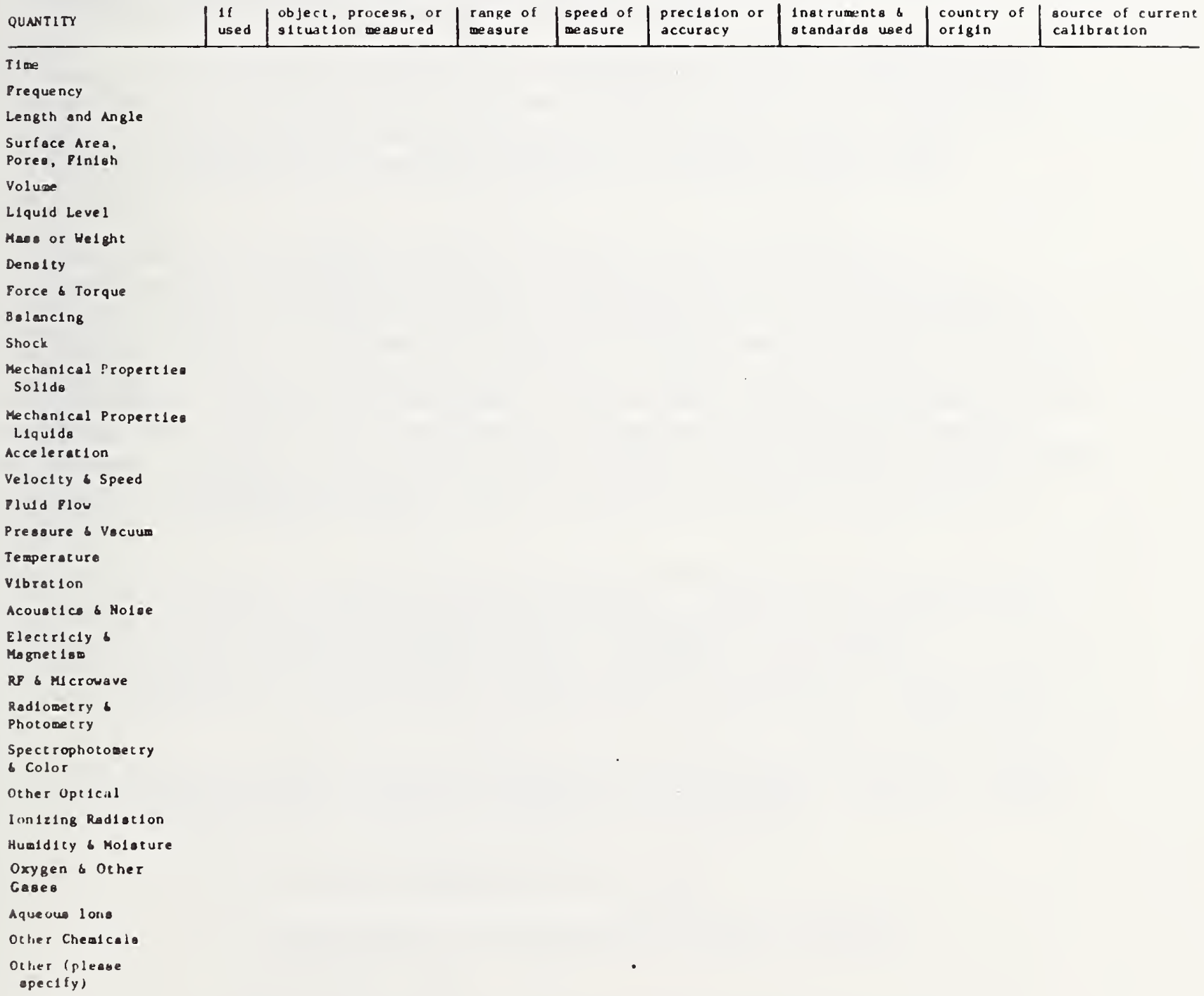


APPENDIX D

DRAFT OF A LETTER TO ACCOMPANY THE QUESTIONNAIRE

(to be edited, adjusted to fit Korean style, and translated)

The Korea Standards Research Institute seeks your thoughtful help so that it can better serve your organization. K-SRI, described in the enclosed booklet, exists to advise Korean factorles, Institutions, and govermental agencles on how to ensure sound technical measurements wherever they are needed in our nation. Measurement is always a basic step in all of science and all of technology.

When our Government analyzed the experience of other industrialized nations and took account of our own circumstances, it resolved that industry, the defense and economic health of our nation, needs a strong measurement (metrology) research institute. Therefore, President Park ordered the immediate creation of K-SRI.

There has been planning assistance from the U.S. Agency for International Development and the General Electric Company of the U.S.A. The U.S. National Bureau of standards is putting 75 years of experience at our disposal. We are bullding fine laboratories, buying unique equipment, and hiring technical staff at the highest level of knowledge. We want all of them to serve you in the measurement field. It is impossible for every company to employ specialists in every field, so in the U.S.A. and In Japan, also, even the largest companies rely on technical support from a national focal point in metrology. Korea now has $\mathrm{K}-\mathrm{SRI}$, too!

We have a general idea of what metrological problems are faced by our nation, but our knowledge w111 become more exact and our service to you of more benefit by asking you to complete the attached questionnaire. If you wish to receive help in filling it in, call us by telephone and we will send a speclalist to help you in the task.

If you do not like this procedure, please do not ignore this request. We would appreclate a letter written in your words. Tell us, within the confidentiallty assured by law, the following:

I. a. what size organization you have;

b. what the size and expertise of your technical personnel are;

c. what essential measurements you now make; 
d. What measuring instruments you use for these purposes (consider repair, maintenance, and calibration problems);

e. what better measurements you wish you could make (for example, to resolve disagreements between production and inspection stations); and

f. what measurement devices you plan to build or market.

Maybe these questions sound as if they do not concern you or as if they relate to areas in which you need no help; however if:

II. a. your product quality tends to vary more than you had hoped (or there is rapid build-up of scrap before a fault in production can be rectified);

b. raw materials or other supplies vary too much or are short in measure;

c. production controls are difficult to maintain;

d. your product quality cannot be justly defended against consumer complaints;

e. interchangeability of parts is troublesome; or

f. measurement or inspection costs are too high, perhaps through use of older methods or seeking more accuracy than needed;

then chances are you have a problem in metrology.

Of course, many of the problems can be cured by reference to other existing organizations or to available literature. K-SRI is only involved with its research and its facilities if the metrological problem cannot be solved except with methods at or close to the current state of the art, such as for:

III. a. closest needed tolerances;

b. the most precise or accurate measurements, physical or chemical;

c. critical non-destructive evaluation;

d. mutual interference of devices such as between advanced electronic systems; and 


\section{e. resolution of discrepancies or disagreements be- tween conflicting authorities in measurement fields.}

Think about these things, answer the questions at the direction of the most senior officials in your Company, but let responsible persons in the procurement, maintenance, quality control, production, and marketing sections of your organization add to the input. Above all, plan to be and keep in touch with K-SRI. Working with K-SRI will uplift your profits and industrial development in our nation. Metrology is one key leading this nation into higher technology. 
NBS.114A (REV. 7.73)

\begin{tabular}{|c|c|c|}
\hline $\begin{array}{l}\text { U.S. DEPT. OF COMM. } \\
\text { BIBLIOGRAPHIC DATA } \\
\text { SHEET }\end{array}$ & $\begin{array}{l}\text { I. PUIBLICATION OR REPORT NO. } \\
\text { INBSIR 77-1382 }\end{array}$ & 3. Recipient's Accession No. \\
\hline \multicolumn{2}{|l|}{ 4. TITLF, AND SUBTITLE } & 5. Publication Date \\
\hline \multirow{2}{*}{\multicolumn{2}{|c|}{$\begin{array}{l}\text { VISIIING TEAM REPORT ON } 1977 \text { INDUSTRIAL SURVEY IN ROREA } \\
\text { ON PRECISION MEASUREMENTS AND STANDARDS }\end{array}$}} & November 1977 \\
\hline & & 6. Performing Organization Code \\
\hline \multicolumn{2}{|c|}{$\begin{array}{l}\text { 7. AUTHOR(S) } \\
\text { KunMo Chung, H. Steffen Pelser, Raymond C. Sangster }\end{array}$} & 8. Performing Organ. Report No. \\
\hline \multirow{2}{*}{\multicolumn{2}{|c|}{$\begin{array}{l}\text { 9. PERFORMING ORGANIZATION NAME AND ADDRESS } \\
\text { NATIONAL BUREAU OF STANDARDS } \\
\text { DEPARTMENT OF COMMERCE } \\
\text { WASHINGTON, D.C. } 20234\end{array}$}} & 10. Project/Task/Work Unit No. \\
\hline & & 11. Contract/Gtant No. \\
\hline \multirow{2}{*}{\multicolumn{2}{|c|}{$\begin{array}{l}\text { 12. Sponsoring Organization Name and Complete Address (Street, City, State, ZlP) } \\
\text { Industrial Advancement Administration } \\
\text { (under Agency for International Development Loan }\end{array}$}} & $\begin{array}{l}\text { 13. Type of Report \& Period } \\
\text { Covered } \\
\text { Flnal }\end{array}$ \\
\hline & & 14. Sponsoring Agency Code \\
\hline
\end{tabular}

15. SUPPLEMENTARY NOTES

Work carried out under the Memorandun of Understanding

16. A RSTRACT (A 200-word or less factual summary of most significant information. If document includes a significant bibliography or literature survey, mention it here.)

The Rorean Standards Research Institute is a recently founded organization that is to serve functlons in Korea generally equivalent to those of the Institute for Basic Standards of NBS in the U.S.A. To plan R-SRI's metrological services to industry and other Korean laboratorles, a survey of lndustrial needs 18 belng conducted with advice from NBS. This report describes some basic facts about K-SRI, the survey plan, as well as principally, conclusions and recomendations given by the authors during their brief consultation visit to Korea, May 22-28, 1977.

A main questlonnalre was drafted, wlth an accompanying letter for subsequent translation and adaptation to Rorean public/private sector interaction. The survey should provide vislbillty for K-SRI, awareness of Industrial needs to 1 ts 8 taff, and means to develop a sound plan for 1 ts prlority programs.

17. KEY WORDS (six to twelve entries; alphabetical order; capitalize only the first letter of the first key word unless a proper name; separated by semicolons)

Development ass18tance; Industr1al1zation; Industry survey; Korea south; Metrology; Questionnaire; Standards inst1tute; Survey

18. AVAILABILITY X Unlimited

[-] For Official Distribution. Do Not Release to NTIS

] Order From Sup. of Doc., U.S. Government Printing Office Washington, D.C. 20402, SD Cat. No.C.13

[X] Order I'rom Nacional Technical Information Service (NTIS) Springfield, Virginia 22151

\begin{tabular}{|l|c|}
\hline $\begin{array}{l}\text { 19. SECURITY CLASS } \\
\text { (THIS REPURT) }\end{array}$ & 21. NO. OF PAGES \\
UNCL ASSIFIED & 27 \\
\hline $\begin{array}{l}\text { 20. SECURITY CLASS } \\
\text { (THIS PAGE) }\end{array}$ & $\begin{array}{l}\text { 22. Price } \\
\text { UNCLASSIFIED }\end{array}$ \\
\hline
\end{tabular}






$s$

'

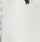

.

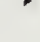

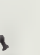

$$
\text { . }
$$


